\title{
Zagadnienia realizacji filmów z ukrytej kamery stanowiących część telewizyjnych programów rozrywkowych
}

Images

vol. XIV/no. 23

Poznań 2014

ISSN 1731-450x

$[2][a]$

W połowie lat sześćdziesiątych kinematografia dokumentalna[b] wzbogaciła się o nowy gatunek: telewizyjny film kręcony z ukrytej kamery dla celów rozrywkowych.

Do czasu powstania tego gatunku dokument stronił od rozrywki, w której immanentnie zdawał się tkwić element inscenizacji, poza może zapisami filmowymi przedstawień satyrycznych czy monografii artystów estrady (np. Adolfa Dymszy), gdzie tylko forma, tzn. rejestracja autentycznego wydarzenia, jakim jest spektakl teatralny, należała do dziedziny dokumentu, natomiast treść była oczywistą inscenizacją.

Niekiedy w kronice filmowej można było zanotować elementy rzeczywistości oglądanej w satyrycznej deformacji (np. temat z roku 1964: o zamykaniu na kłódkę głównych wejść sklepowych, a otwieraniu jedynie bocznych; temat z roku 1963: o Polakach, których nieodłącznym rekwizytem stała się teczka, pokazano wtedy m.in. żołnierza i księdza - z teczkami właśnie). Komizm tych tematów polegał wyłącznie na wyłowieniu i zarejestrowaniu zabawnej obserwacji, spotęgowanej przez umiejętny montaż i odpowiednią ilustrację muzyczną.

Zasadniczym zadaniem filmu realizowanego z ukrytej kamery, stanowiącego część składową widowiska telewizyjnego / programu telewizyjnego typu „show”, jest wywołanie określonych, zamierzonych emocji, częstokroć kosztem walorów poznawczych czy dydaktycznych. Specyfika filmu „z ukrytą kamerą” polega na tym, że to krótka (trzypięciominutowa) produkcja, stanowiąca na ogół fragment większej (inscenizowanej) całości. Jest ona ograniczona pewnymi koniecznymi warunkami, których spełnienie stanowi podstawę zamierzonego odbioru przez widza.

[3]

1. Głównymi bohaterami takiego utworu są ludzie przypadkowi, przechodnie, niezdający sobie sprawy ze swego uczestnictwa w przygotowanym zdarzeniu oraz niewiedzący, że ich uczestnictwo jest rejestrowane na taśmie filmowej i dźwiękowej.

2. Wydarzenie, w którym przechodnie uczestniczą, nie może stwarzać żadnego niebezpieczeństwa fizycznego ani nie może powodować strat materialnych u mimowolnych aktorów.

[a] Numeracja w nawiasach kwadratowych odnosi się do numeru strony w maszynopisie. [b] Wnioskując na podstawie dalszej części wstępu, autorowi chodzi o kinematografię polską [przyp. - P.P.]. 
3. Wydarzenie musi mieć smak autentyku, to znaczy: nie może być retuszowane np. postsynchronem, zdjęciami trickowymi ani też zabiegami technicznymi, podnoszącymi jakość zdjęcia kosztem wiarygodności.

4. Elementy, z których zbudowano film, muszą być powszechnie znane, ich zrozumienie nie może wymagać specjalistycznego wykształcenia odbiorcy. Np. przeciętnego widza nie rozśmieszy błędne odczytanie hieroglifów egipskich ani nieprawidłowe działanie licznika Geigera. Nie oznacza to wcale, że dziedziny wiedzy ścisłej nie stanowią tworzywa w twórczości rozrywkowej, np. specjalistyczne zagadnienia naukowe są $\mathrm{z}$ powodzeniem prezentowane $\mathrm{w}$ teleturniejach.

Do szybkiego rozwoju i wykrystalizowania gatunku, jakim są filmy z ukrytą kamerą, przyczynił się przede wszystkim rozwój techniki zdjęciowej.

a. Kamera 16-milimetrowa przestała być zabawką dla amatorów, a stała się sprzętem zawodowym. Jest lekka, łatwa do ukrycia dzięki niewielkim rozmiarom, a jej 120-metrowa kaseta rejestruje 10 minut ekranowych.

b. Taśma filmowa odznacza się taką czułością, że umożliwia robienie zdjęć bez sztucznego światła, we wnętrzach i miejscach zaciemnionych. Jest przy tym niedroga, co pozwala na [4] znaczne jej zużycie. Wydaje się jednak, że przyszłość należy tu do magnetycznego zapisu obrazu.

c. Optyka. Obiektyw - transfokator umożliwia wybranie i zaakcentowanie przez operatora interesującego detalu, a po chwili ukazanie planu ogólnego całej sceny, co powoduje, że mimo uwięzienia w ukryciu zdjęcia mogą być niezwykle ruchliwe i dynamiczne.

d. Zapis dźwięku. Przy filmach z ukrytą kamerą dźwięk rejestrowany jest za pomocą bezprzewodowo pracujących miniaturowych mikrofonów, tzw. mikroportów, ukrytych w pobliżu miejsca wydarzeń.

Sądząc z listów nadchodzących do telewizji po emisji moich programów, w których prezentowałem także filmy z ukrytą kamerą, utwory te cieszą się dużą popularnością, chociaż jest jasne, że różnią się niekorzystnie od reszty programu niską jakością obrazu i dźwięku, a nieświadomi wykonawcy ról $\mathrm{w}$ takich produkcjach są zestawiani z najpopularniejszymi zawodowymi aktorami zawodowymi. Jakie są przyczyny tego zjawiska?

Jednym z podstawowych prawideł wywoływania śmiechu jest pokazanie obiektu ośmieszanego w sposób, który w widzu wytworzy przekonanie o własnej przewadze (fizycznej lub intelektualnej) nad przedstawionym osobnikiem.

Przeważnie, aby osiągnąć zamierzoną reakcję, sugeruje się widzowi utożsamienie $\mathrm{z}$ podstawionym medium, tzn. osobnikiem reprezentującym wyższą inteligencję czy sprawność w przedstawionym kon- 
flikcie. To jest zasada żartu w dialogu, komentarzu, narracji. Natomiast w żarcie filmowym często to medium nie występuje: widz, obserwując np. zmaganie człowieka ze stawiającą złośliwy opór materią, bawi się tym lepiej, im bardziej jest podświadomie przekonany o ewentualnej własnej przewadze w podobnej sytuacji.

[5] Aby wywoływać przewidywane reakcje (śmiech), oba te systemy muszą się opierać na podstawowej konwencji: założeniu, że wydarzenie odbyło się naprawdę. Im bardziej do rzeczywistości będą zbliżone realia inscenizacji, tym spontaniczniej nastąpi wyładowanie emocjonalne; im bardziej umowne, tym do węższego trafi kręgu odbiorców [inscenizacja - P.P.]. I tak - clown cyrkowy, wylewający sobie wiadro $\mathrm{z}$ autentyczną wodą na głowę, wywoła bardziej bezpośrednią reakcję niż aktor przedstawiający to samo wydarzenie w pantomimie.

W „ukrytej kamerze”, podobnie zresztą jak w większości filmów dokumentalnych, nie ma potrzeby zakładania żadnej umowności. Siła oddziaływania tego gatunku wywodzi się przede wszystkim $\mathrm{z}$ autentyzmu zarejestrowanych reakcji - uczestnicy zostają ośmieszeni „na czysto”, bez uciekania się do jakichkolwiek konwencji. Zadanie swoje wykonują w sposób naturalny, nie dostrzegając często absurdu sytuacji (który należy jak najbardziej zakamuflować), i dopiero kontekst całości, zestawienie wszystkich elementów danej sceny wywołuje reakcję u widza.

Cóż może być np. zabawnego w wyrazie twarzy uczynnego, uprzejmego przechodnia, przytrzymującego drabinę, na którą wspina się przystojna ekspedientka, aby zmierzyć pękniętą górną szybę wystawy sklepowej?

Kiedy jednak poinformujemy, że ekspedientka odziana jest niezwykle kuso i skąpo oraz że podnosząc ręce z miarką odsłania nieco swoich wdzięków, widz zaczyna w inny sposób rozumieć znaczenie ukradkiem rzucanych spojrzeń uczynnego przechodnia, a rzecz staje się zabawna. Tak więc - umieszczenie [sytuacji - P.P.] w kontekście wywołało przewidywaną reakcję, będącą celem wszystkich zabiegów realizacyjnych.

Prześledźmy teraz cykl produkcyjny filmu z ukrytą kamerą.

[6] Kolejne etapy to:

1. Opracowanie założeń inscenizacyjnych

2. Okres przygotowawczy

3. Zdjęcia

4. Montaż i udźwiękowienie

\section{Opracowanie założeń inscenizacyjnych}

Naczelnym zadaniem realizatorów filmu z ukrytą kamerą jest wywołanie fizycznego działania u nieświadomego odbiorcy. To działanie fizyczne jest odzwierciedleniem konkretnego przeżycia czy stanu emocjonalnego (na przykład zdziwienia, oburzenia, zaskoczenia, pożądliwości, naiwności itd.), a potencjalnie - także negatywnych cech 
charakteru, z którymi nikt się dobrowolnie nie zdradza. Reakcja zgodna z przyjętymi normami postępowania nie wzbudziłaby żadnego zainteresowania. Niemożliwe jest jednak nakreślenie ścisłych ograniczeń, wszystko bowiem zależy od konkretnej sytuacji.

Teoretycznie, słuszne jest na przykład założenie, że należy unikać pokazywania na ekranie ludzi śmiejących się, ponieważ taka reakcja powinna być poprzedzona ukazaniem komicznego wydarzenia, które wywołało wybuch wesołości. To wydarzenie, jeżeli rzeczywiście było zabawne, nie potrzebuje suflera, aby widz zrozumiał żart (co więcej, odbiorca przed ekranem mógłby to odebrać jako wotum nieufności dla jego poczucia humoru). Dlatego w komediach filmowych unika się pokazywania ludzi rozbawionych przedstawioną sytuacją.

Natomiast człowiek śmiejący się w sytuacji, która jego samego ośmiesza, np. grubas śmiejący się z hipopotama, zdradzany mąż ubawiony opowieścią o rogaczu, kryje w sobie potencjalne możliwości wywołania pożądanej reakcji widza. Tylko że widz w tym wypadku śmieje się ze śmiechu skompromitowanego, a więc ustawia się ponad wydarzeniem.

[7] Inną możliwością ukazania śmiechu jest zaproponowanie wspólnej zabawy w widowisku typu show czy rewii. W prawidłowo przeprowadzonym spektaklu tego typu telewidz identyfikuje się z widownią przekazywaną przez obraz telewizyjny. Warunkiem powodzenia będzie tu autentyzm zachowania i rozbawienia widzów w studio.

Przy opracowaniu założeń ukrytej kamery realizator tak planuje przebieg wydarzenia, aby sprowokować ekspozycję przewidywanych reakcji. Istnieją tu dwie metody: bierna i aktywna.

a. Metoda bierna polega na ukryciu kamery w miejscu, gdzie człowiek obnaża swoje oblicze, sądząc, że nikt go nie obserwuje. Przykładem tej metody jest seria zdjęć człowieka przed lustrem w publicznej toalecie. Kamera ukryta za półprzezroczystym lustrem rejestruje błyskawiczne zabiegi upiększające, grymasy itp.

Metoda ta, dzięki całkowitemu usunięciu elementu inscenizacji, daje efektowne wyniki, jest jednak bardzo żmudna i czasochłonna, a ponieważ nie można sformować takiego materiału w anegdotę, film musi być bardzo ograniczony w czasie.

b. Metoda aktywna. Podpatrywany zostaje sprowokowany do działania przez odpowiednio spreparowany rekwizyt, podstawionego „naszego człowieka” lub oba czynniki jednocześnie.

Tu, oczywiście, kierując wydarzeniem, można wywołać szereg reakcji i skonstruować je w kształt dramaturgiczny. Oto przykładowo trzy scenariusze, ilustrujące możliwości tej metody.

1. Rekwizyt. Budka telefoniczna ze specjalnie spreparowaną żelazną klamką, umocowaną za pomocą elektromagnesu. Kiedy potencjalny rozmówca bierze za klamkę, chcąc wejść do środka budki, elektromagnes zostaje wyłączony. Zaskoczony przechodzień nie wie, co zrobić z trzymaną w ręku klamką, której gładka powierzchnia nie pozwala się domyślić, w jaki sposób przedmiot był umocowany. 
2. [8] Nasz człowiek. Aktorka przebrana za pomoc domową szuka porady u Cyganek włóczących się po ulicy. Zakładamy kontrast między tekstami wróżb a autentycznymi informacjami o aktorce, które poda komentarz.

3. Nasz człowiek + rekwizyt. Na zacisznej uliczce leży połówka banknotu 100-złotowego. Kiedy spostrzegawczy przechodzień podnosi banknot, zjawia się nasz człowiek i proponuje odkupienie tej połówki, mówiąc, że przed chwilą znalazł drugą. Oferuje bardzo niską cenę (10 złotych). W dalszym ciągu targowania okaże się, że połówki pochodzą z różnych banknotów.

Zacytowane tu scenariusze zapowiadają wydarzenia dość codzienne, które nie wzbudzą takiego zdumienia czy zaskoczenia, jakiego dostarczyłoby zetknięcie z sytuacją metafizyczną. Niestety, ograniczone środki techniczne uniemożliwiają zorganizowanie bardziej złożonych wydarzeń irracjonalnych, niepojętych. Do nich należy np. projekt pt. Spotkanie z niewidzialnym człowiekiem.

W odludną uliczkę wjeżdża samochód sportowy (kabriolet) z opuszczonym dachem. W samochodzie nie ma nikogo (jest sterowany drogą radiową). Auto zatrzymuje się przy jedynym przechodniu, który oczywiście musi przebywać w polu widzenia kamery. Z wnętrza samochodu pada pytanie o dojazd do jakiejś ulicy (rozmowę przez nadajnik radiowy prowadzi nasz człowiek ukryty obok aparatury filmowej). Posiadając tak oprzyrządowany pojazd, można by także zrobić przejazd bardziej uczęszczaną ulicą i zarejestrować reakcję np. kierującego ruchem milicjanta.

Niezależnie od tego, czy przygotowane wydarzenie będzie się mieścić w kategoriach spraw zrozumiałych, czy nie, powinno w zasadzie naruszać ustalony porządek rzeczy i przyzwyczajeń.

[9] Mimo że istnieje ryzyko zdemaskowania zamierzeń realizatorów wskutek niezwykłości pomysłu, to $z$ drugiej strony zerwanie z codziennością, zaproponowanie innego widzenia realnego świata nadaje nowe znaczenie staremu pojęciu magii kina. Dotychczas bowiem każdy techniczny trick filmowy stwarzał cudzysłów, oddzielający od normalnego świata, akceptowanego i niewzruszonego w swoich prawach. W momencie kiedy widz wie, że obraz przedstawia rzecz niemożliwą/nieistniejącą, musi akceptować odpowiednią konwencję, aby percypować dalej bez protestu. W wypadku filmu z ukrytą kamerą nie istnieje potrzeba zgody na konwencję.

Mała dziewczynka prosi przechodnia o pomoc w zarzuceniu na plecy worka z płytami chodnikowymi o wadze ok. $150 \mathrm{~kg}$. Uczynni przechodnie sprawdzają osobiście ciężar bagażu, którego sami nie są w stanie unieść. Po chwili widzą, że dziewczynka uniosła swój ciężar i lekkim krokiem odchodzi. Widz jest świadkiem czaru, dziejącego się w szarej, konkretnej rzeczywistości - obserwował zmagania przechodniów, widział też, jak dziewczynka sama uniosła worek. Oczywiście, w końcu demaskuje się widzowi zasadę podstępu: przechodnia w pewnym momencie zagaduje drugi „nasz człowiek”, a dziewczynka 
zasłania autentyczne płyty specjalnie spreparowaną skrzynią na kółkach, odsłaniając jednocześnie drugi worek wypełniony atrapami płyt, wykonanymi z lekkiego tworzywa sztucznego.

\section{Okres przygotowawczy}

Po ustaleniu założeń inscenizacyjnych rozpoczyna się najdłuższy czasowo etap. Wykonanie odpowiednich, często skomplikowanych rekwizytów i sprawdzenie ich przydatności oraz skuteczności jest gwarancją sprawnego przeprowadzenia zdjęć.

[10] W dużym, mało uczęszczanym hallu wieżowca mieszkalnego droga od wejścia do windy wyłożona jest papierami, co na ogół wszyscy rozumieją jako ochronę niedawno umytej podłogi. Papiery wysmarowane są klejem, który z trudnością daje oderwać się od buta.

W przytoczonym wypadku znalezienie właściwego kleju zajęło kilka dni, ponieważ kolejno dostarczane próbki albo nie miały dostatecznej przylepności, albo przeciwnie: groziły uszkodzeniami obuwia lub ich niepokojący wygląd z daleka ostrzegał potencjalne ofiary.

Duże trudności sprawia także znalezienie odpowiedniego „naszego człowieka”. Powinien to być osobnik odważny, inteligentny, rozmowny, mający umiejętności improwizacji i błyskawicznego dostosowania się do zaistniałej sytuacji. Niestety, ludzie zawodowo do tego przygotowani, a więc aktorzy estradowi, konferansjerzy itp., są wykluczeni z racji swojej popularności i łatwości zdemaskowania. Dlatego wykonawców roli „naszego człowieka” rekrutuje się spomiędzy młodych, nieznanych ogółowi aktorów i uzdolnionych amatorów wyszukanych w odpowiednich środowiskach.

W „instruktażowym” filmie z ukrytą kamerą, dotyczącym techniki zawierania błyskawicznych znajomości, wystąpił pewien student, którego prawdziwym powołaniem zdaje się być zainteresowanie płcią odmienną. W tym wypadku zalety osobiste osobnika okazały się identyczne z poprzednio wymienionymi cechami "naszego człowieka” (w stopniu tak przydatnym dla potrzeb filmu, że nakręciłem z nim od razu szereg dalszych tematów).

Należy jednak pamiętać, że po wystąpieniu w kilku „ukrytych kamerach”, wskutek dużej popularności tego rodzaju programów, wykonawca może zostać zdemaskowany przez osobę, którą zaczepia na ulicy. [11] Liczba tematów z tym samym „naszym człowiekiem” jest więc ograniczona czasem realizacji jednej serii. Ze względów produkcyjnych i organizacyjnych na ogół realizuje się od razu kilka filmów tego typu, a następnie używa w kolejnych odcinkach programu telewizyjnego.

Szkolenie (a właściwie próby) polega na przeprowadzeniu zadania bez ukrytej kamery i mikrofonu. W czasie tych prób następuje konfrontacja założeń koncepcji z rzeczywistością, co jest w konsekwencji przyczyną wielu, często zasadniczych, korekt. 
Istnieje u „naszych ludzi” powszechna tendencja do wysuwania własnej osoby na plan pierwszy - mając bowiem świadomość swojego występu, starają się, często nieświadomie, panować nad całością sceny.

My, realizatorzy, rozumiemy ich zadanie jako dużo skromniejsze: „nasz człowiek” to katalizator reakcji podpatrywanego, jeżeli więc zbytnio zaakcentuje swą przewagę nad osobą zaczepioną, może wzbudzić niechęć widza, czego chcielibyśmy uniknąć.

Z drugiej strony, należy pamiętać, że zbytnia powściągliwość „naszego człowieka” nie wywoła planowanej reakcji nagabywanego przechodnia.

Próby z zawodowym prestidigitatorem przyniosły rozczarowanie. Zadanie „naszego człowieka” polegało na podejściu do klienta opuszczającego kasę w sklepie samoobsługowym, podrzuceniu mu do kieszeni jakiegoś towaru (czekolady, paczkowanej szynki) i następnie zasugerowaniu, że klient nieświadomie wyniósł ów przedmiot, omijając kasę i płacenie. Dalej „nasz człowiek” proponował stałą współpracę $\mathrm{w}$ tego rodzaju procederze. $\mathrm{W}$ toku realizacji prestidigitator, który normalnie swoje zadanie wykonywał bezbłędnie, nie potrafił się wyzwolić od zawodowego zagadywania i demonstrowania wydarzenia niewidzialnym widzom, [12] o których podświadomie pamiętał, przez co film nabrał niepotrzebnie akcentów występu estradowego.

Można natomiast zanotować pozytywne wyniki wystąpienia dziecka w roli „naszego człowieka”. Okazało się, że dorosłym nie przychodzi na ogół do głowy, iż mogą paść ofiarą podstępu osoby małoletniej, natomiast stosunkowo łatwo jest znaleźć dziecko, które bez oporów wewnętrznych i tremy spowodowanej świadomością filmowania wykona powierzone zadanie. Dziecko traktuje występ po prostu jako zabawę, a należy pamiętać, iż nawet zwyczajna zabawa jest dla niego działaniem autentycznym. Nie można jednak zapominać, że u młodego aktora stosunkowo szybko następuje moment przesycenia i zmęczenia - dlatego $\mathrm{w}$ pracy z nim powinno się często robić przerwy i w ogóle zrezygnować z prób.

Powodzenie zdjęć zależy w dużym stopniu od znalezienia właściwego miejsca do ukrycia aparatury zdjęciowej. Powinno to być pomieszczenie stosunkowo obszerne. Ekipa realizatorska liczy co najmniej 4 osoby przy zdjęciach niemych oraz 6 osób przy zdjęciach dźwiękowych (reżyser, operator, asystent operatora, dźwiękowiec, obsługa magnetofonu, kierownik produkcji), ale w praktyce jest liczniejsza (asystent reżysera, scenograf, względnie rekwizytor i „nasz człowiek”).

Najdogodniejsze okazały się do tych celów pomieszczenia sklepowe, ponieważ duża powierzchnia wystawy pozwala robić zdjęcia z dala od szyby, co powoduje, że kamera jest niemal całkowicie niewidoczna, a ponadto znajduje się na ogół na poziomie ulicy, co ułatwia zdejmowanie zbliżeń twarzy. Duża powierzchnia tzw. lustrzanych (a więc 
niedeformujących) szyb umożliwia panoramowanie za poruszającym się człowiekiem, zaś drzwi sklepowe ułatwiają szybkie porozumiewanie się z „naszym człowiekiem” czy powtórne ustawienia rekwizytów.

Doświadczenie wykazało, że przegroda w postaci szyby jest wystarczającym [13] zasłonięciem kamery, zwłaszcza że na ogół filmowana akcja nie rozgrywa się bezpośrednio przed sklepem.

Na 12 zrealizowanych przeze mnie dotychczas filmów z ukrytą kamerą: 9 realizowałem z pomieszczeń sklepowych, 2 z prywatnego mieszkania i 1 bez żadnej osłony ( $\mathrm{z}$ balkonu).

Zrezygnowanie $\mathrm{z}$ ukrycia było $\mathrm{w}$ ostatnim wypadku możliwe, ponieważ zdejmowane wydarzenie miało miejsce na ruchliwej ulicy (Nowy Świat [w Warszawie - P.P.]), gdzie ma się do czynienia z wieloma elementami przyciągającymi uwagę przechodniów oraz dużym stłoczeniem spieszących się ludzi, zmuszonych do rozglądania się na poziomie oczu po najbliższym otoczeniu dla uniknięcia kolizji.

Im mniejszy ruch na ulicy, tym większa możliwość zdemaskowania ukrytej kamery. Im ruch większy, tym większa możliwość przeprowadzenia eksperymentu $z$ wybranym osobnikiem, bez ingerencji osób trzecich.

Jeżeli zdjęcia mają przedstawiać wnętrze, wybrany obiekt powinien być jasny (przeszklony), kamera ukryta od strony źródła światła. Należy wówczas przewidzieć ewentualność wymiany istniejących żarówek na własne o intensywniejszym świetle.

$\mathrm{Z}$ tych głównie powodów należy wybór obiektów, w których odbędą się zdjęcia, przeprowadzić z operatorem.

Przy wyborze miejsc dla zdjęć dźwiękowych należy pamiętać, że pracujące silniki elektryczne zakłócają czystość nagrania dźwiękowego, w stopniu uniemożliwiającym odczytanie zapisu.

\section{Zdjęcia}

W normalnych warunkach okres zdjęciowy trwa od dwóch do pięciu godzin, zaś od szybkości pracy ekipy realizatorskiej zależy [jego P.P.] sukces czy porażka. Instalowanie aparatury zdjęciowej przeprowadzać należy oczywiście w miarę dyskretnie, chociaż - przynajmniej w wypadku kręcenia filmów w Warszawie, gdzie pojawienie się [14] pracującej ekipy nie wzbudza większego zainteresowania - niebezpieczeństwo zdemaskowania nie jest zbyt wielkie.

Po zainstalowaniu kamery i ustaleniu granic jej pola widzenia umieszcza się rekwizyty i uzgadnia z wykonawcą teren poruszania.

Jak dotąd, możliwość porozumiewania się drogą radiową istnieje tylko dla wykonawcy, „naszego człowieka”, który ma ukryty mikrofon, natomiast nie dysponuje odbiornikiem. Kamera zostaje więc uruchomiona na sygnał lub zapowiedź „naszego człowieka”, a zatrzymana według wyczucia ukrytych realizatorów. Po pierwszych zdjęciach przeprowadza się korektę założeń i wykonawstwa.

W temacie Nowa nazwa usunięto tabliczkę z nazwą popularnej ulicy Koszykowej i zastąpiono ją nazwą „ul. G. Fitelberga”. „Nasz 
człowiek" udawał cudzoziemca, który z ręcznie narysowanym planem w ręku, kalecząc polszczyznę, rozpytywał o Koszykową. Realizatorzy zakładali, że zaskoczeni informatorzy będą komentowali, względnie oburzali się na widok zmienionej nazwy. W rzeczywistości jednak z uporem wyjaśniali cudzoziemcowi, że jest w poszukiwanym miejscu, że nie należy przejmować się inną tabliczką. Jedynym prawdziwie komicznym okazał się przechodzień, który słysząc wykoślawioną „Z angielska” polszczyznę wykonawcy, zaczął udzielać mu informacji, kalecząc polszczyznę „z rosyjska”, dodając do niej śpiewny akcent i słowa „ponimajesz”, „w poriadku” itp.

Mizerne efekty tego założenia (których przyczyną wydawała się, po pierwsze, pozytywna skądinąd niechęć do krytykowania naszych spraw przed cudzoziemcem, a po drugie obawa, że słabo władający językiem polskim obcokrajowiec nie zrozumie wyjaśnień) zmusiły nas do przeprowadzenia zmiany założenia.

„Nasz człowiek” odrzucił więc eleganckie walizy i części garderoby [15], by z teczką w ręku wystąpić jako przyjezdny z prowincji. Ten prosty zabieg otworzył usta warszawiakom: wyjaśniali, oburzali się, snuli przypuszczenia o przyczynach przemianowania ulicy.

Wszelkie korekty inscenizacji wprowadza się w początkowym stadium zdjęć. Czas trwania realizacji wynosi, jak wspomniałem, od trzech do pięciu godzin i jest podyktowany przede wszystkim wytrzymałością psychiczną „naszego człowieka”. Najlepsze efekty osiąga się $\mathrm{w}$ dwóch pierwszych godzinach zdjęć, kiedy w konfrontacji z rzeczywistością przeprowadzono konieczne zmiany założeń. Po tym czasie zauważyć można u głównego wykonawcy tendencje dominowania w dialogach nad podpatrywanym przechodniem, skłonność do stereotypowych sformułowań oraz przyspieszanie przebiegu wydarzeń przez przerywanie rozmówcy.

Te niekorzystne zmiany są zauważalne jedynie dla obserwujących wydarzenie realizatorów - sam główny wykonawca jest na ogół przekonany, że wykonuje swoje zadanie coraz lepiej.

Niekiedy do skrócenia czasu realizacji zmusza zdemaskowanie ekipy i tworzenie się grupek postronnych obserwatorów. Ponieważ wszelka interwencja jest bezskuteczna, bo zwiększyłaby tylko liczbę zainteresowanych, pozostaje jedynie zarządzenie dłuższej przerwy, względnie przeniesienie się $\mathrm{w}$ inne miejsce.

W zależności od tematu potrzebna jest różna liczba podpatrywanych osobników.

W filmie Panienka z ksiązka „naszym człowiekiem” była dziewczyna z pokaźnym biustem, mocno wydekoltowana, która stała na przystanku autobusowym i czytała książkę (w chłodny i deszczowy dzień). Kamera rejestrowała przechodniów, zerkających na dziewczynę (czynili to prawie wszyscy). Właściwym miejscem okazała się tu ulica Nowy Świat w godzinach od 15 do 17, to znaczy w czasie, kiedy 
tą wąską arterią, [16] uniemożliwiającą zbytni pośpiech, przechodzą tłumy ludzi. Próba realizacji tego samego tematu na szerokim chodniku ulicy Marszałkowskiej, w godzinach przedpołudniowych, dała bardzo niezachęcające efekty.

Do zdemaskowania kamery dochodzi niezbyt często i przeważnie wystarczy parę słów wyjaśnienia, aby zlikwidować incydent, ponieważ wydaje się, że mimowolnym aktorom sprawia pewną przyjemność, kiedy dowiadują się, iż zostaną pokazani w telewizji, nawet za cenę ośmieszenia. Jedynym wyjątkiem w mojej praktyce okazało się wydarzenie z osobnikiem, który zrobił ordynarną awanturę rzekomej ekspedientce, „naszemu człowiekowi”, w sklepie z kryształami. Kiedy wyjaśniono mu, że była to inscenizacja dla filmu z ukrytą kamerą, zorientował się, że kamera zarejestrowała jego niekulturalne zachowanie i to, rzecz jasna, pogorszyło sytuację.

Oczywiście, mimo że nakręcony materiał przedstawiał się bardzo interesująco, nie można go było - wbrew wyraźnym zastrzeżeniom uczestnika wydarzenia - użyć do filmu.

W dwu wypadkach, kiedy sprowokowani do działania przechodnie zorientowali się, że są obiektami zdjęć, zaczęli improwizować jakiś żart, aby wyjść z honorem z sytuacji (jeden pocałował „naszego człowieka”, który był w tym wypadku przystojną dziewczyną, drugi zasłonił się gazetą, udając nagłe pogrążenie w lekturze).

W czasie kręcenia zdjęć do tematu Wróżby cygańskie wszystkie Cyganki, które wróżyły naszej aktorce, od razu wykrywały mikrofon, ale nie kojarzyły go zupełnie z kamerą (którą też wykrywały bezbłędnie). Pytały aktorkę, czy jest Amerykanką, podejrzewając na podstawie doświadczeń $\mathrm{z}$ obwieszonymi sprzętem zdjęciowym zagranicznymi turystami, że takie musi być zastosowanie wiszącego na szyi i niezbyt dokładnie ukrytego mikrofonu. Po twierdzącym oświadczeniu aktorki zabierały się spokojnie do wróżenia.

[17] Filmy z ukrytą kamerą w naszym klimacie można kręcić jedynie w ciepłej porze roku. Niemożliwe jest bowiem zatrzymywanie przechodniów w warunkach zmuszających do spiesznego chronienia się przed zimnem i opadami. Ponadto długość i natężenie światła ekspozycyjnego jedynie latem stwarzają odpowiednie warunki do wykonywania zdjęć.

\section{Montaż}

Ostateczna koncepcja filmu, często zasadniczo różniąca się od [pierwotnych - P.P.] założeń, powstaje przy stole montażowym, po kilkakrotnym przejrzeniu całego materiału. Wszystkie poprzednio wykonane zabiegi doprowadziły do zebrania możliwie wielu różnorodnych wydarzeń, zazwyczaj odmiennych w przebiegu i czasie trwania.

W paru wypadkach prawie cały film wypełniało jedno wydarzenie - najzabawniejsze z kilku podobnych: nie stosowałem wówczas żadnych skrótów, podkreślając protokólarny charakter zapisu. 
Tą metodą posłużyłem się przy opracowaniu tematu Połówka banknotu. Połówkę banknotu znalazła grupka nastolatków i kiedy zjawił się „nasz człowiek” z drugą połową, młodzi ludzie przeprowadzili długi i gorący spór o prawo posiadania całego znaleziska.

Założeniem Lepiących papierów (które wyłożone na wymytej klatce schodowej przylepiały się do butów) było wywołanie odruchów protestu i irytacji, tymczasem przylepieni przechodnie zdawali się jedynie zakłopotani, reakcje nie były specjalnie zabawne - natomiast ich sposób poruszania i odczepiania złośliwych przedmiotów okazał się bardziej interesujący dla naszych potrzeb. W rezultacie serię brodzeń różnych ludzi zmontowaliśmy w rytmie popularnego walca, tworząc $\mathrm{w}$ ten sposób zabawny quasi-balet. $\mathrm{Z}$ bogactwa różnych reakcji wybrano te, które tempem i układem [18] ciała kojarzyły się z figurami tanecznymi. Selekcja materiału doprowadziła do stworzenia nowej rzeczywistości.

Dopiero też na etapie montażu istnieje możliwość wykorzystania zasady spiętrzenia efektu komicznego dzięki powtórzeniom sytuacji. Jest rzeczą oczywistą, że seria prezentowanych wydarzeń będzie składała się z elementów podobnych, różniących się tylko niewielkimi szczegółami. Ustalenie odpowiedniej kolejności wzmiankowanych zdarzeń potęguje wrażenie powstałe przy pierwszej ekspozycji.

Z zasady tej w fabularnym filmie komediowym lubili korzystać tacy amerykańscy komicy, jak [Charlie] Chaplin, Flip i Flap (przewrócenie na skórce od banana) oraz [Jacques] Tati (seria zderzeń z latarnią w Moim wujaszku[a]) i inni.

Warunkiem uzyskania pożądanego efektu przy powtórzeniu jest pokazywanie coraz zabawniejszych wydarzeń w coraz to szybszym rytmie, spowodowanym przez użycie skrótów montażowych.

Przystępując do realizacji Wróżb cygańskich zamierzaliśmy zarejestrować autentyczne teksty przepowiedni, a następnie skonfrontować [je] z wydarzeniami, które naprawdę nastąpiły w ciągu miesiąca od spotkania z wróżbiarką. Cóż, kiedy owe przepowiednie brzmiały mgliście i niezrozumiale. Na szczęście, zarejestrowany przy okazji na taśmie system wyłudzania pieniędzy przez sprytne Cyganki okazał się właściwym tematem filmu. Wystarczyło jedynie zaakcentować ważniejsze momenty (tj. znikanie banknotów) odpowiednim komentarzem.

Komentarz jest podstawowym spoiwem całego filmu i ma wielorakie zadanie.

a) Wyjaśnia założenia filmu i sposób jego realizacji. Jest to funkcja dosyć istotna, gdyż widz musi uwierzyć w prawdziwość wydarzenia, a uprzedzony o jego przebiegu ma tak potrzebne do zabawy [19] poczucie wyższości nad uczestnikami sytuacji. Dlatego istotną częścią zdjęć do filmu z ukrytą kamerą jest nakręcenie obrazu demaskującego wykorzystaną w nim technikę.

[a] Film produkcji francusko-włoskiej z roku 1958 [przyp. - P.P.]. 
b) Wykrywa i podkreśla komizm przedstawionego obrazu. Często zdarza się, że o dodatkowym akcencie decyduje drobny szczegół, detal niezbyt precyzyjnie zarejestrowany przez kamerę. Wystarczy zwykle, że komentator zwróci uwagę widza np. na bezradnie rozłożone ręce zaczepionego osobnika, żeby ów widz zauważył komizm sytuacji. Niekiedy komentatora może zastąpić na chwilę zatrzymanie akcji („klatka stop") lub wykonanie nieruchomej fotografii z wycinka właściwej klatki.

c) Wyciąga wnioski i konkluzje. Ulubioną formą jedynego komentatora i autora komentarzy do filmów z ukrytą kamerą, Jacka Fedorowicza (z którym je wszystkie wspólnie realizowałem), jest opatrywanie tekstu tonem brzmiącym możliwie naukowo i rzeczowo. Taki komentarz sugeruje, że film ma charakter doświadczenia naukowego czy tekstu socjologicznego, a w zestawieniu z rzeczywistością oglądaną na ekranie brzmi to bardziej komicznie, niż gdyby komentator zaśmiewał się z podpatrywanych.

Ukryta kamera ma zresztą rzeczywiście duże wartości poznawcze i traktowanie jej jedynie jako figla płatanego bezbronnym ludziom przez zorganizowaną grupę, dla wyszydzenia ich przed olbrzymim audytorium, byłoby spłyceniem i zwulgaryzowaniem możliwości artystycznych, jakie stwarza.

Niekiedy funkcję komentarza może spełniać ilustracja muzyczna. Powszechne jest używanie jako podkładu dźwiękowego gotowych nagrań. W wypadku ilustrowania filmu popularnym utworem muzycznym, którego melodia kojarzy się z określonym tekstem czy nastrojem, u widza powstaje podświadomie niemal łączenie znaczenia muzyki $\mathrm{z}$ oglądanym obrazem. I tak np. muzyka $\mathrm{z}$ Love story $[a]$ podkreśla uczuciowe akcenty zabiegów „naszego człowieka” [20] w roli Don Juana, a Pieśń burłaków[b], ilustrująca zmagania „dziewczynki-siłacza” i jej pomocników, zaakcentuje ciężar i trud podniesienia na plecy stukilogramowego ładunku płyt chodnikowych.

\section{XXX}

Z tego krótkiego omówienia procesu realizacji filmów z ukrytą kamerą wynika jasno, że każdy z etapów powstawania utworu wymaga nieustannego korygowania i budowania konstrukcji efektu finalnego, w odróżnieniu od dotychczasowych wymagań przy realizacjach filmowych. Realizacja normalnego filmu fabularnego czy dokumentalnego sprowadza się w ostatecznym efekcie do ilustrowania scenariusza. Reżyser nie może np. zrezygnować w połowie zdjęć $\mathrm{z}$ postaci bohatera czy zamierzonego tematu, i to nie tylko ze względów organizacyjno-finansowych, bowiem próby całkowitej improwizacji, z odrzuceniem poprzednio przyjętych założeń (a takowe próby bywały), przynosiły mizerne rezultaty.

[a] Amerykański melodramat [1970] w reżyserii Arthura Hillera (autor muzyki: Francis Lai).

[b] Rosyjska pieśń tradycyjna (tekstowo odwołująca się do wysiłku robotników nadwołżańskich, czyli tytułowych burłaków), spopularyzowana między innymi przez jazzowy band Glenna Millera (1941). 
Film z ukrytą kamerą jest utworem krótkim, a więc łatwo poddającym się zabiegom często zmieniającym diametralnie pierwotne założenia, co jest niemożliwe w długim metrażu, gdzie logika konstrukcji dramaturgicznej daje szansę zmian w niewielkim tylko zakresie.

$\mathrm{Z}$ nakręconego do filmu z ukrytą kamerą materiału można zrobić utwory, których komizm będzie zbudowany na zupełnie różnych założeniach. Dla przykładu: pierwsza wersja Lepiących papierów była psychologicznym testem na reakcje przeciętnego warszawiaka na oczywisty nieporządek - zaś ostateczna wersja, „balet” zniecierpliwionych, oklejonych przechodniów, nie miała nic wspólnego z pierwotnym założeniem.

Oczywiście, takie zabiegi są możliwe tylko z filmem krótkim, nieosadzonym w żadnym konkretnym kontekście.

[21] Spośród istniejących form filmowych, produkcja z ukrytą kamerą najbardziej zbliża się konstrukcyjnie do gagu filmowego, z tym że gag jest jednak podporządkowany naczelnemu założeniu całości.

Dzięki takim swoim cechom film z ukrytą kamerą stanowi praktyczną szkołę dla reżysera i scenarzysty, pozwalającą skonfrontować zamierzenia $z$ oporem stawianym przez materię, [przez] tworzywo, jakim są dla niego ludzie i wydarzenia.

Jeżeli chodzi o oddziaływanie na widza, film z ukrytą kamerą kryje w sobie potencjalne możliwości satyry obyczajowej i środowiskowej. Może też okazać się dokumentem rejestrującym sposób bycia i postawy w życiu codziennym, dzięki absolutnej szczerości i spontaniczności zachowania nieświadomych wykonawców. Takie wartości zawiera chyba nasz eksperyment z „podrywaczem” i Cyganką.

Nierozwiązaną do tej pory kwestią jest pokazywanie na ekranie ludzi nieuprzedzonych o udziale w zdjęciach. W większości wypadków nieświadomy udział w filmie z ukrytą kamerą nie pociąga za sobą ujemnych konsekwencji towarzyskich i społecznych, ale dzieje się to kosztem selekcji przeprowadzonej przez realizatorów, często wpływającej na pogorszenie jakości utworu.

W jednym z [e wspomnianych już - P.P.] filmów, kręconym w Supersamie, „nasz człowiek” proponował klientom wspólne wynoszenie ukradkiem towarów ze sklepu. Mimo że udało się nakręcić kilku chętnych do tego rodzaju współpracy, którzy tym samym zgodzili się na dokonanie przestępstwa, materiał ten nie został użyty ze względu na konsekwencje, jakie zapewne spotkałyby niedoszłych przestępców (a następnie prawdopodobnie również realizatorów). Przypuszczam jednak, że gdyby od razu po zdjęciach porozumiano się ze sfilmowanymi, to przynajmniej w kilku wypadkach uzyskano by za wynagrodzenie zgodę na użycie nakręconego materiału. Moment uprzedzenia pozwoliłby ponadto na poinformowanie o przyszłym występie w filmie najbliższego otoczenia [22] sfilmowanego osobnika, co na pewno złagodziłoby przypuszczalnie negatywną opinię.

Zdajemy sobie sprawę, że stałe demaskowanie przez realizatorów techniki zdjęć w krótkim czasie uniemożliwiłoby kręcenie na danym terenie (poza tym, w gotowym utworze pokazuje się nie więcej niż 10\% podpatrzonych osobników). 
Wydaje się jednocześnie, iż [w] wypadku tematów drażliwych lub mogących przynieść pewne szkody podpatrywanym, lepiej ryzykować metodę uprzedzania niż rezygnować z interesującego materiału. W wypadkach mniej drastycznych, gdzie celem jest najwyżej łagodne ośmieszenie, wystarczy pokazać wydarzenia w sposób taktowny, ewentualnie [dodać] kilka słów przeproszenia. Jest to ważne także $z$ innych powodów: widz, któremu realizatorzy przedstawiają się wyłącznie jako zawsze triumfujący szydercy, może sam poczuć się zagrożony i nabrać niechęci do prezenterów. Dlatego niekiedy nie boimy się pokazać nieudanego eksperymentu, w którym podpatrywany demaskuje ukrytą kamerę. Drugim powodem stosowania takiego rozwiązania jest potwierdzenie autentyczności wydarzenia, bo oczywiście nie byłoby potrzeby przepraszania wynajętych wykonawców.

Jako pierwszy realizował [w Polsce - P.P.] filmy z ukrytą kamerą Jerzy Gruza. Były to telewizyjne programy rozrywkowe, które prowadził Jacek Fedorowicz. W roku 1972, korzystając z ich doświadczeń, nakręciłem wspólnie z Fedorowiczem 12 krótkich metraży tego typu; autorem zdjęć był mający już doświadczenie w tym gatunku filmowym operator TV, Paweł Minkiewicz.

\section{Nota redakcyjna}

Opublikowany w tym numerze pisma „Images” tekst pracy Stanisława Barei Zagadnienia realizacji filmów z ukrytej kamery stanowiacych część telewizyjnych programów rozrywkowych oparty jest na oryginalnym maszynopisie, dostępnym w bibliotece PWSFTviT w Łodzi (sygnatura: D 1014). Prace redakcyjno-korektorskie polegały na:

a) uporządkowaniu interpunkcji

b) usunięciu powtórzeń oraz kilku usterek gramatycznych

c) drobnych przekształceniach w obrębie szyku zdaniowego.

Wszelkie uzupełnienia leksykalne w tekście oddane zostały przez zastosowanie nawiasu kwadratowego. Wszystkie przypisy są mojego autorstwa.

Serdeczne podziękowania za pomoc i życzliwość przy redagowaniu pracy magisterskiej Stanisława Barei (oraz przy powstawaniu tekstów jej towarzyszących) zechcą przyjąć: pani Hanna Kotkowska-Bareja oraz pan Jacek Fedorowicz. 